\title{
Rancang Bangun Sistem Monitoring Dan Pemberi Pakan Otomatis Ayam Anakan Berbasis Internet Of Things (IOT)
}

\author{
Indra Gunawan', Hamzan Ahmadi2, Muhammad Ramdhani Said ${ }^{3}$ \\ 1, 2,3 Program Studi Teknik Informatika, Fakultas Teknik Universitas Hamzanwadi \\ *artha_3119@yahoo.com
}

\begin{abstract}
Abstrak
Peternakan merupakan salah satu penyuplai pangan terbesar setelah pertanian. Banyak dari para peternak melakukan segala sesuatu untuk meningkatkan kualitas ternaknya. Cara yang biasa digunakan para peternak ayam yaitu dengan cara manual seperti pengecekan suhu, dan pengecekan ketersediaan pakan. Oleh karena itu perlu dibuat alat monitoring suhu dan pemberian pakan ayam secara otomatis, dimana dalam penelitian ini berbasis loTs (Internet of Things). Alat ini menggunakan sensor DHT11 untuk mengukur suhu dalam kandang, Arduino Uno dan NodeMCU ESP 8266 sebagai mikrokontroller dan aplikasi blynk sebagai alat monitoring suhu. Alat ini terdiri dari beberapa bagian yang saling terhubung. Mulai dari sensor DHT11 mengukur suhu, lalu dikirim ke mikrokontroller setelah itu di proses, kemudian dikirim ke webserver blynk sehingga bisa diakses dan ditampilkan oleh aplikasi monitoring. Sedangkan Pemberian pakan ayam dapat di permudah menggunakan motor servo sebagai pintu pemberi pakan ayam yang bekerja dengan system penjadwalan, kemudian untuk ketersediaan pakan akan diukur dengan berat yang sudah ditentukan. Jika berat mencapai angka kurang dari atau sama dengan $400 \mathrm{gram}$, maka sensor loadcell akan mengirimkan notifikasi ke blynk dengan pesan. Hasil pada penelitian ini disimpulkan dapat memonitoring suhu dalam kandang dan memberikan pakan secara otomatis walaupun masih belum maksimal.
\end{abstract}

Kata Kunci : Internet of Things, Sensor DHT11, Pakan Otomatis

\begin{abstract}
Farm is one of the largest food suppliers after agriculture. Many of the breeders do everything to improve the quality of their livestock. The usual way used by chicken farmers are by manual means such as temperature checking, and checking the availability of feed. Therefore it is necessary to create an automatic temperature monitoring and chicken feeding tool, which in this research based on loTs (Internet of Things). It uses DHT11 sensors to measure temperature in cages, Arduino Uno and NodeMCU ESP 8266 as microcontrollers and blynk applications as temperature monitoring tools. It consists of several interconnected parts. Starting from the DHT11 sensor measuring the temperature, then sent to the microcontroller after it is processed, then sent to the blynk webserver so that it can be accessed and displayed by the monitoring application. While chicken feeding can be made easier using servo motor as a door feeder chicken that works with scheduling system, then for the availability of feed will be measured by the specified weight. If the weight reaches a number less than or equal to 400 grams, then the loadcell sensor will send a notification to blynk with the message. The result of this researchs can monitor the temperature in the cage and provide feed automatically even though it still not maximal.
\end{abstract}

Keyword: Internet Of Things, DHT11 Sensor, Automatic Feed

\section{Pendahuluan}

Peternakan merupakan salah satu penyuplai pangan terbesar setelah pertanian. Banyak dari para peternak melakukan segala sesuatu untuk meningkatkan kualitas ternaknya.[1] Cara yang biasa digunakan para peternak ayam yaitu 
dengan cara manual seperti pengecekan suhu, pengecekan ketersediaan pakan.

Suhu lingkungan sangat berpengaruh bagi pertumbuhan ayam. Pada prinsipnya pertumbuhan dan efisiensi penggunaan makanan yang maksimum tidak dapat dicapai, jika ayam yang dipelihara kondisi suhu lingkungannya tidak sesuai[2]. Untuk mengatasi masalah pada suhu tersebut, dilakukan dengan cara menggunakan lampu sebagai penghangat, ketika suhu ruangan sudah mencapai batas yang ditentukan, maka peternak akan mematikan lampu secara manual, Hal ini dapat menyita banyak waktu, karena peternak harus ke- lokasi kandang untuk mengontrol suhu kandang.Untuk mengatasi masalah ini penulis ingin membuat sebuah system Monitoring suhu dan pemberi pakan otomatis ayam anakan berbasis loT. Sistem ini merupakan alat yang mampu memonitoring suhu dan memberikan pakan ayam secara otomatis. Sistem monitoring suhu dan pemberi pakan ayam otomatis ini berbasis Internet of Things yang mampu mempermudah peternak untuk memonitoring suhu pada kandang serta memberikan pakan secara otomatis dari jarak dekat maupun jauh.

\section{Tinjauan Pustaka}

\subsection{Penelitian Terkait}

Laksono dan Arief Budi dimana dalam penelitian ini menjelaskan suatu alat untuk kandang ayam yang dapat mengendalikan suhu, kelembaban dan pakan secara otomatis berbasis ATMega328. Alat ini dirancang untuk memudahkan para peternak dalam memberi pakan, serta memonitoring suhu dan kelembaban. Alat ini menggunakan sensor DHT11 yang berfungsi sebagai pendeteksi suhu dan kelembaban yang ada di dalam kandang ayam. Lampu untuk penerangan dan meningkatkan suhu dalam ruang kandang. Jika suhu melebihi $30 \circ \mathrm{C}$, maka blower aktif untuk mengeluarkan suhu dalam kandang yang berlebihan. Sedangkan untuk meningkatkan kelembaban menggunakan mist maker yang mengeluarkan uap air dan mist maker akan off jika kelembaban di atas $65 \%$. Pemberian pakan ayam dapat di permudah menggunakan motor servo sebagai pintu pemberi pakan ayam yang bekerja di atur oleh sensor photo dioda yang terkoneksi dengan cahaya infra merah.[3]

Menurut Deni Kurnia dan Vina Widiasih perkembangan alat otomatisasi sampai saat ini sudah banyak diimplementasikan dalam berbagai bidang, salah satunya dalam bidang peternakan. Penelitian yang dilakukan dalam bidang ini diantaranya tentang pengontrolan sistem otomatis pemberian pakan ayam menggunakan mikrokontroler ATMega8535 atau Arduino yang dikombinasikan dengan aplikasi fuzzy dan smartphone yang bertujuan untuk meningkatkan efisiensi dan efektivitas pekerjaan 
para peternak. Disisi lain, pesatnya pengguna internet di Indonesia telah membuka potensi para peneliti untuk melakukan pengintegrasian pengontrolan berbasis web. Kondisi ini dapat diakomodasi oleh NodeMCU sebagai mikrokontroler yang terintegrasi dengan WiFi shield. Namun, sampai saat ini belum ada penelitian yang mengimplementasikan NodeMCU dalam sistem otomasi peternakan berbasis web. Sehingga kondisi tersebut menjadi dasar dilakukannya penelitian ini. Luaran penelitian ini adalah untuk membuat prototipe sistem otomasi pemberian pakan ternak berbasis web mengunakan NodeMCU. Diharapkan hasil penelitian ini dapat diimplementasikan untuk membantu para peternak ayam agar hasil panennya menjadi optimal, dengan pola pekerjaan yang efektif dari segi waktu dan eifisien dari segi finansial. Hasil penelitian menunjukkan sistem dapat bekerja dengan baik. Data menunjukkan, terjadi peningkatan efisiensi yang cukup signifikan dalam penggunaan pakan tanpa mengurangi bobot ternak pada saat panen dilakukan. Untuk implementasi dalam jumlah yang lebih besar, diperlukan penelitian lebih lanjut dalam mendesain sistem yang mampu mengcover kebutuhan peternakan dengan parameter pengontrolan yang lebih kompleks. [4] Menurut Nina Lestari, Ketut Abimanyu, Iqra Hadi Setyo dan Deden Hadian Ayam broiler merupakan jenis ayam ternak yang pertumbuhannya dipengaruhi oleh suhu lingkungan, sehingga pengaturan suhu dalam kandang perlu dilakukan untuk menghindari turunnya produktivitas bahkan resiko kematian ayam ternak. Sistem pangatur suhu kandang menggunakan mikrokontroler ATmega 328, sensor suhu LM35, switch kipas / blower dan lampu pijar diatur dengan Relay. Jika suhu yang terukur diatas $29 \circ \mathrm{C}$, relay akan diperintahkan oleh mikrokontroler untuk menyalakan atau mematikan kipas/blower dan jika suhu yang terukur dibawah $26 \circ \mathrm{C}$, relay akan diperintahkan untuk menyalakan atau mematikan lampu pijar.[5]

Menurut Indra Gunawan, Hamzan Ahmadi dalam penelitiannya Sistem Monitoring Dan Pengkabutan Otomatis Berbasis Internet Of Things (IoT) Pada Budidaya Jamur Tiram Menggunakan NodeMCU dan Blynk. Alat ini menggunakan sensor suhu DHT11 sebagai pengukur suhu dan kelembaban, NodeMCU ESP 8266 sebagai mikrokontroler dan aplikasi Blynk sebagai alat kontrol dan tempat di tampilkannya hasil pengukuran. Alat ini terdiri dari beberapa bagian yang saling terhubung. Mulai dari sensor DHT11 mengukur suhu dan kelembaban lalu di kirim ke mikrokontroler setelah itu di proses, kemudian di kirim ke webserver Blynk sehingga bisa di akses dan ditampilkan oleh aplikasi kontrol. Selain itu juga mikrokontroler terhubung dengan relay yang berfungsi sebagai swich dari 
pompa air sprayer yang bisa di kontrol melalui aplikasi[6][7].

\subsection{Landasan Teori}

\section{Rancang Bangun}

Rancang merupakan serangkaian prosedur untuk menerjemahkan hasil analisis dari sebuah sistem kedalam bahasa pemrograman untuk mendeskripsikan dengan detail bagaimana komponen-komponen sistem diimplementasikan. Tujuan dari merancang ialah untuk memberi ilustrasi yang jelas dan lengkap kepada programmer dan ahli teknik yang terlibat[8].

Bangun merupakan kegiatan menciptakan sistem baru atau mengganti dan memperbaiki sistem yang telah ada secara keseluruhan. Jadi dapat disimpulkan bahwa Rancang Bangun merupakan penggambaran, dari perencanaan, dan pembuatan sketsa atau pengaturan dari beberapa elemen yang terpisah kedalam satu kesatuan yang utuh dan berfungsi. Dengan demikian pengertian rancang bangun merupakan kegiatan menerjemahkan hasil analisa ke dalam bentuk paket perangkat lunak kemudian menciptakan sistem tersebut atau memperbaiki sistem yang sudah ada.[8][9]

\section{Monitoring}

Pada penelitian D. Widjanarko [10] Monitoring merupakan pengawasan, yang berarti proses pengendalian, pemeriksaan, pengamatan dan juga pengoreksian dari seluruh kegiatan yang ingin diketahui.

\section{Suhu}

Pada penelitian JS. Saputra[11] Suhu merupakan suatu besaran yang menyatakan derajat panas dingin suatu benda, dan nama alat yang digunakan untuk mengukur suhu disebut thermometer. Dalam menjalani kehidupan, masyarakat cenderung untuk mengukur suhu menggunakan indera peraba. Namun setelah perkembangan teknologi yang begitu pesat, maka diciptakanlah suatu alat untuk mengukur suhu dengan valid yang disebut dengan thermometer.

\section{Internet of Things}

Pada penelitian J.S Saputra dkk,[11] Internet of Things atau sering juga disebut $l o T$, merupakan sebuah konsep yang bertujuan untuk memperluas manfaat dari konektivitas internet yang tersambung secara terus-menerus yang memungkinkan untuk menghubungkan mesin, peralatan, dan benda fisik lainnya dengan memanfaatkan sensor jaringan dan aktuator untuk memperoleh data dan mengelola kinerjanya sendiri, sehingga memungkinkan mesin dapat berkolaborasi dan bahkan bertindak berdasarkan informasi baru yang diperoleh secara independen. 


\section{Sensor DHT 11 (Suhu)}

Sensor DHT11 merupakan modul sensor yang dapat mengukur suhu dan kelembaban udara di sekitarnya. Sensor ini sangat mudah digunakan bersama dengan Arduino maupun Wemos. Memiliki tingkat stabilitas yang sangat baik serta fitur kalibrasi yang sangat akurat.Sensor suhu DHT11 ini termasuk sensor yang memiliki kualitas terbaik, dinilai dari respon, pembacaan data yang cepat, dan kemampuan antiinterference[11]. Sensor suhu dapat dilihat pada gambar 1.

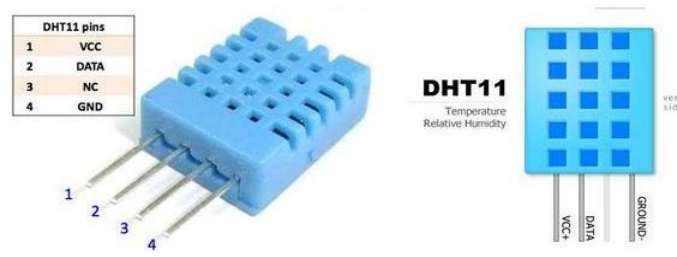

Gambar 1 : Sensor DHT11

\section{NodeMCU V3}

NodeMCU merupakan platform loT open source berbiaya rendah yang pada awalnya menggunakan firmware ESP8266 Wi-Fi SoC dari Espressif Systems, terdiri dari perangkat keras berupa System On Chip ESP8266 dari ESP8266 buatan Espressif System, yang menggunakan bahasa pemrograman scripting Lua. Istilah NodeMCU secara default sebenarnya mengacu pada firmware yang digunakan dari pada perangkat keras development kit.

Alat ini juga support dengan software Arduino IDE dengan melakukan sedikit perubahan board manager pada Arduino IDE dan juga bahasa Lua. Jika menggunakan Arduino IDE menggunakan firmware yang cocok yaitu firmware keluaran dari AiThinker yang support AT Command. Untuk penggunaan tool loader Firmware yang di gunakan adalah firmware NodeMCU.

Sebelum menggunakannya, Board ini harus di Flash terlebih dahulu agar support terhadap tool yang akan digunakan[12]. Esp 8266 dapat dilihat pada gambar 2 ;

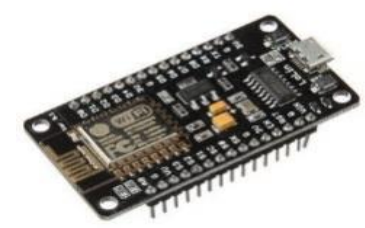

Gambar 2 : Esp8266

\section{Arduino Uno}

Arduino disebut sebagai platform elektronik yang open source, berbasis pada software dan hardware yang fleksibel dan mudah digunakan, yang ditujukan untuk seniman, desainer, hobbies dan setiap orang yang tertarik dalam membuat suatu objek atau lingkungan yang interaktif. Arduino sebagai sebuah platform komputasi fisik (Physical Computing) yang open source pada board input output sederhana, maksudnya platform komputasi fisik disini merupakan sebuah sistem fisik yang interaktif dengan penggunaan software dan hardware yang dapat mendeteksi dan merespons situasi dan kondisi[13]. Berikut 
merupakan tampilan dari arduino uno dapat dilihat pada gambar 3 ;

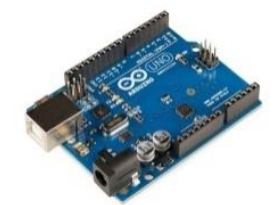

Gambar 3 : Arduino Uno

\section{Arduino IDE}

Arduino IDE merupakan suatu software (perangkat lunak) yang digunakan untuk memprogram board Arduino, dibutuhkan aplikasi IDE (Integrated Development Environment) bawaan dari Arduino. Aplikasi ini berguna untuk membuat, membuka, dan mengedit source code Arduino (Sketches, para programmer menyebut source code arduino dengan istilah "sketches"). Selanjutnya, jika kita menyebut source code yang ditulis untuk Arduino, maka kita juga akan menyebutnya sebagai sketch. Sketch merupakan source code/sintax yang berisi logika dan algoritma yang akan diupload ke dalam IC mikrokontroller[13]. Software inilah yang akan kita gunakan untuk membuat program pada Esp 8266 NodeMCU. Berikut merupakan tampilan dari arduino IDE, dapat dilihat pada gambar 4 ;

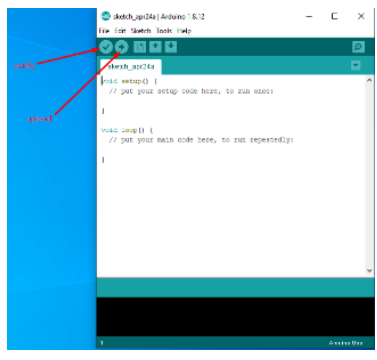

Gambar 4 : Arduino IDE

9. Lampu Bolam
Lampu bolam atau lampu dop merupakan cahaya buatan yang dihasilkan melalui penyaluran arus listrik melalui filament yang kemudian memanas dan menghasilkan cahaya. Terdapat Kaca yang menyelubingi filament, ia berfungsi sebagai pemanas, pemanas tersebut menghalangi udara masuk untuk berhubungan dengan filament, sehingga tidak akan merusak langsung akibat oksidasi. Lampu ini sering digunakan di kandang untuk menghangatkan ayam yang masih kecil[14]. Berikut merupakan tampilan dari lampu dop, dapat dilihat pada Gambar 5 ;

Gambar 5 : Lampu Dop

\section{Motor Servo}

Motor servo merupakan sebuah perangkat atau aktuatorputar (motor) yang dirancang dengan sistem control umpan balik loop tertutup (servo), sehingga dapatdisetting atau diatur untuk menentukan posisi sudut dari poros output motor. Motor servo merupakan perangkat yang terdiri dariserangkaian gear, motor DC, rangkaian kontrol dan potensiometer. Serangkaian gear yang melekat pada poros motor DC akan memperlambat putaran poros dan meningkatkan torsi motor servo, sedangkan potensiometer dengan perubahan resistansinya saat motor berputar berfungsi sebagai penentu batas posisi putaran poros pada motor servo[15]. 
Berikut merupakan tampilan dari motor servo, dapat dilihat pada Gambar 6 ;

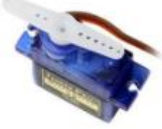

Gambar 6 : Motor Servo

\section{Sensor Berat (Load Cell)}

Load cell (Sensor Berat) merupakan sensor yang cukup populer digunakan untuk pengukuran Force terutama untuk pengukuran berat (timbangan elektronik). Load cell sangat simple dan sangat memudahkan dalam implementasinya. Prisip kerjanya yaitu terjadinya shears atau stress dari suatu benda (misalnya logam). Dalam load cell, shears dan stress ini diwujudkan dalam bentuk perubahan panjang (regangan) permukaan, dan perubahan panjang ini ditangkap oleh sensor sekunder berupa strain gauge yang akan mengubah perubahan panjang (regangan) menjadi perubahan resistansi[16]. Berikut Merupakan tampilan dari Load cell, dapat dilihat pada gambar 7 ;

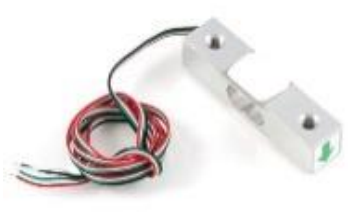

\section{Gambar 7 : Load Cell}

\section{Blynk}

Blynk adalah platform untuk aplikasi OS Mobile (iOS dan Android) yang bertujuan untuk kendali module Arduino, Raspberry Pi, ESP8266,
WEMOS D1, dan module sejenisnya melalui Internet.Blynk juga di artikan sebagai platform yang menggunakan aplikasi iOS dan Android untuk mengontrol Arduino, Raspberry $\mathrm{Pi}$, dan lainya menggunakan internet. Aplikasi ini merupakan wadah kreatifitas untuk membuat antarmuka grafis untuk proyek yang akan diimplementasikan hanya dengan metode drag and drop widget.Blynk tidak terikat pada board tertentu, blynk dapat digunakan pada banyak perangkat keras[17]. Berikut merupakan tampilan dari aplikasi blynk, dapat dilihat pada Gambar 8 ;

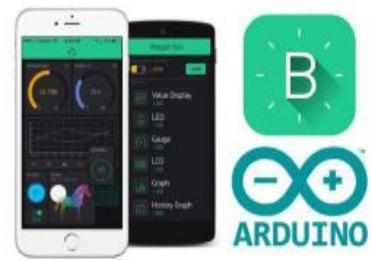

Gambar 8 : Aplikasi Blynk

\section{Relay}

Relay adalah sebuah peralatan listrik yang berfungsi sebagai saklar (switch), relay bekerja pada saat coil relay diberikan tegangan atau arus. Pada saat coil diberikan arus maka pada inti coil akan menjadi magnet yang kemudian menarik kontak-kontak penghubung pada relay tersebut. Pada relay terdapat dua buah kontak yang berbeda yakni kontak NO (Normaly Open) dan NC (Normaly Close). Pada saat kumparan coil belum diberikan arus keadaan kontak NO akan terbuka dan pada saat kumparan coil diberikan arus kontak NO akan terhubung. Untuk 
kontak NC (Normaly Close) pada saat kumparan coil belum diberikan arus kontak NC belum terhubung dan pada saat kumparan coil dialiri arus maka kontak NC menjadi dalam kondisi terhubung[7]. Berikut merupakan tampilan dari relay, dapat dilihat pada gambar 9

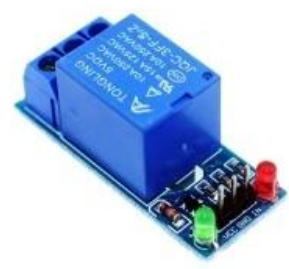

Gambar 9 : Relay

\section{RTC (Real Time Clock)}

Real-Time Clock (RTC) adalah sebuah modul yang berfungsi untuk menjalankan fungsi waktu dan kalender secara realtime karena Dilengkapi Pembangkit Waktu dan Baterai, yang dapat berkomunikasi serial dengan microcontroller Contohnya yaitu Arduino[18]. Berikut merupakan tampilan dari RTC, dapat dilihat pada gambar 10

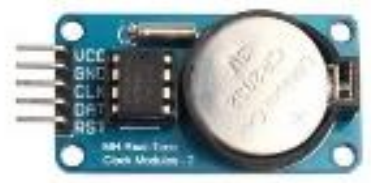

Gambar 10 : RTC

\section{Metode Penelitian}

\subsection{Model Penelitian}

Dalam penelitian ini terdiri dari beberapa objek baik software maupun hardware yakni sensor suhu DHT11, ESP8266 NodeMCU V3, Arduino uno, sensor berat Load cell, motor servo, relay 1 channel, real time clock (RTC), lampu, dan smartphone sebagai hardwarenya. Sedangkan aplikasi blynk sebagai software sekaligus tempat monitoring data hasil bacaan sensor DHT11.

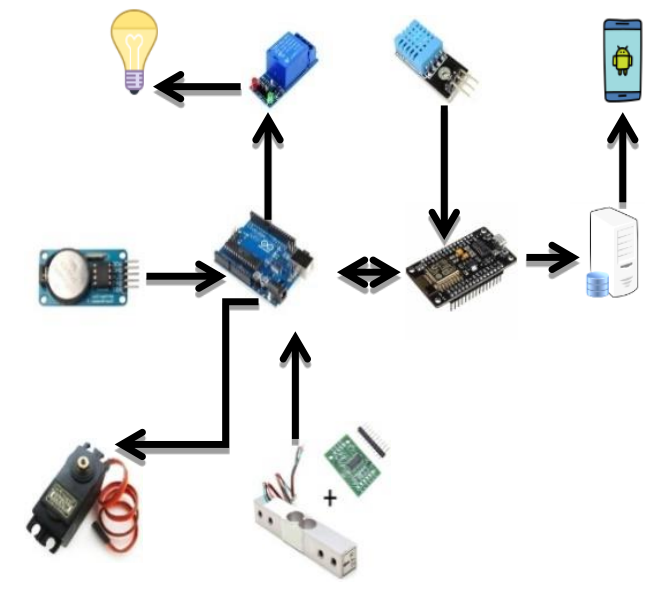

Gambar 11 : Model Penelitian

\section{Hasil dan Pembahasan}

4.1 Rancang Bangun

Perancangan dan bentuk desain alat dapat dilihat pada gambar 13 ;

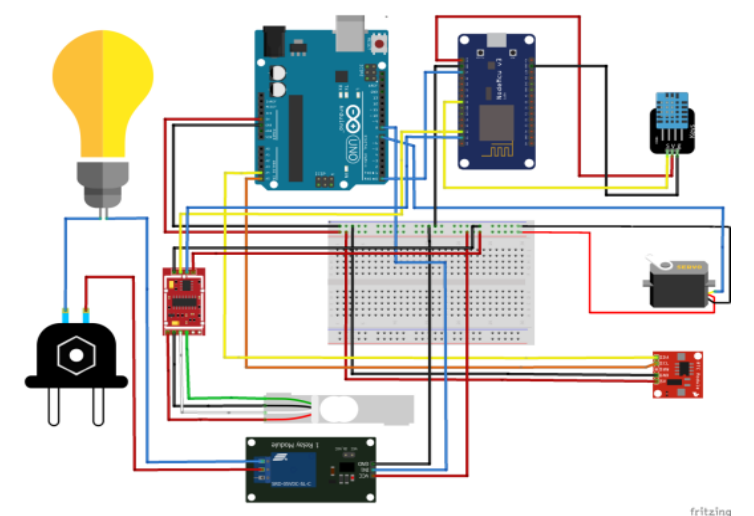

Gambar 12 : Rancangan bentuk desain alat

\subsection{Hasil Aplikasi Antar Muka}

Berikut adalah hasil dalam bentuk aplikasi yang 
akan digunakan untuk memonitoring hasil dari bacaan sensor suhu yang ada didalam kandang, tampilannya dapat dilihat pada gambar 14

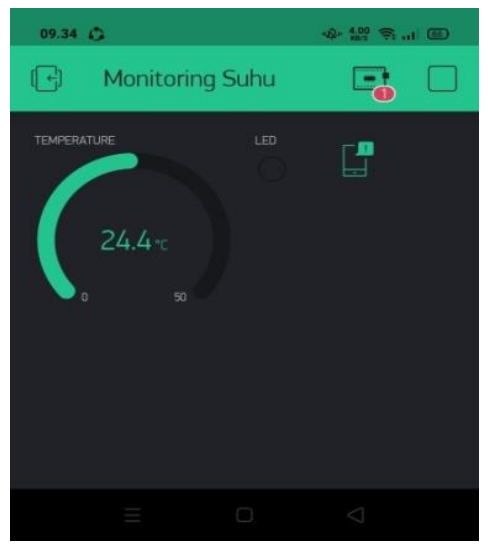

Gambar 13 : Antar Muka Aplikasi

Pada gambar 14 adalah aplikasi yang sudah dirancang pada aplikasi blynk yang sudah siap digunakan oleh pengguna. Pada aplikasi ini terdapat data hasil dari pembacaan sensor suhu dan data hasil bacaan sensor LoadCell yang di olah oleh aplikasi menjadi sebuah notifikasi untuk peringatan ketersediaan pakan, kemudian pada led indikator berfungsi untuk mengetahui apakah lampu pada kandang sedang on/off yang di tandai dengan perubahan warna pada icon led. Cara menggunakannya, harus terhubung dengan internet.

\subsection{Tampilan Bentuk Alat}

\subsubsection{Tampak Wadah Pakan}

Tampak wadah pakan dapat dilihat pada gambar 15 ;

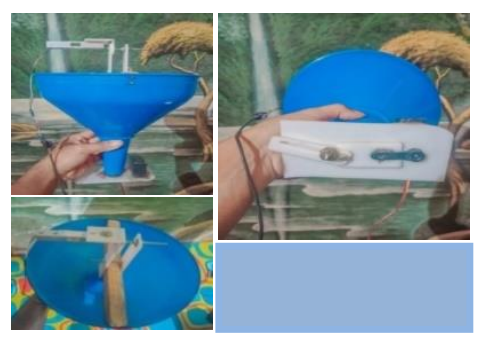

Gambar 14 : Wadah Pakan

\subsection{Tampilan fisik kandang}

Tampilan fisik kandang dapat dilihat pada gambar 16 dan 17 ;

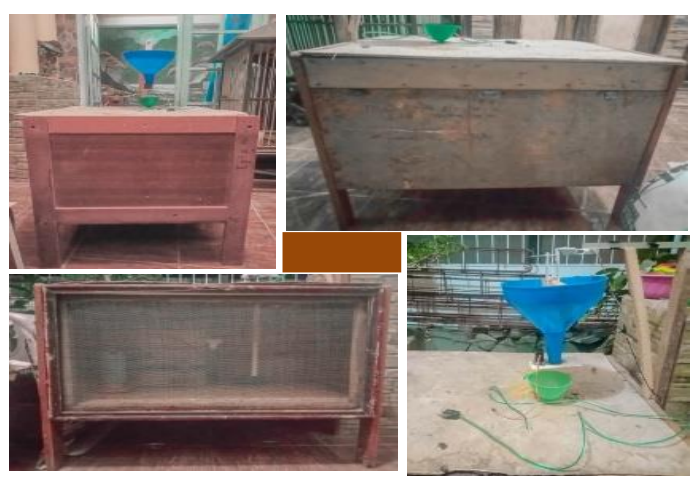

Gambar 15 : Tampilan Kandang

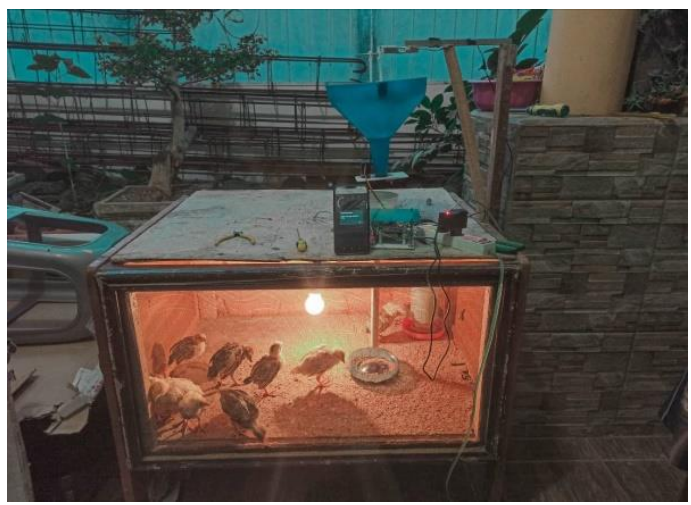

Gambar 16 : Tampak Depan

\subsection{Hasil Pengujian}

Hasil pengujian sistem alat pada kandang ayam anakan

Tabel 1.

\begin{tabular}{|c|c|c|c|c|}
\hline NO & VARIABEL & PROSEDUR UJI & HASIL YANG & HASIL \\
& UJI & & DIHARAPKAN & UJI \\
\hline
\end{tabular}


Infotek : Jurnal Informatika dan Teknologi

Vol. 4 No. 2, Juli 2021

Hal. 151-162

e-ISSN 2614-8773

DOI : $10.29408 / j$ it.v4i2.3562

Link : https://dx.doi.org/10.29408/jit.v4i2.3562

\begin{tabular}{|c|c|c|c|c|}
\hline \multirow[t]{2}{*}{1} & \multirow[t]{2}{*}{ Sensor Suhu } & $\begin{array}{c}\text { Menyalakan } \\
\text { korek api } \\
\text { didekat sensor } \\
\text { DHT dan } \\
\text { melihat } \\
\text { perubahan } \\
\text { suhu }\end{array}$ & $\begin{array}{c}\text { Suhu } \\
\text { berubah } \\
\text { drastis }\end{array}$ & Berhasil \\
\hline & & $\begin{array}{c}\text { Memantau } \\
\text { suhu kandang } \\
\text { antara } 26 \text { - } 29 \\
\text { derajat celcius }\end{array}$ & $\begin{array}{c}\text { Tidak ada } \\
\text { Notifikasi } \\
\text { "Suhu terlalu } \\
\text { tinggi" } \\
\text { dikirim ke } \\
\text { aplikasi } \\
\text { blynk dan } \\
\text { lampu off }\end{array}$ & Berhasil \\
\hline 2 & $\begin{array}{l}\text { Lampu } \\
\text { Bohlam }\end{array}$ & $\begin{array}{l}\text { Menyalakan } \\
\text { lampu ketika } \\
\text { suatu kondisi } \\
\text { terjadi }\end{array}$ & $\begin{array}{l}\text { Lampu } \\
\text { menyala }\end{array}$ & Berhasil \\
\hline 3 & NodeMCU & $\begin{array}{l}\text { Mengirim data } \\
\text { hasil bacaan } \\
\text { sensor suhu ke } \\
\text { blynk }\end{array}$ & $\begin{array}{l}\text { Data hasil } \\
\text { bacaan } \\
\text { sensor suhu } \\
\text { ditampilkan } \\
\text { ke blynk }\end{array}$ & Berhasil \\
\hline 4 & $\begin{array}{c}\text { Data } \\
\text { Visualization } \\
\text { Blynk }\end{array}$ & $\begin{array}{c}\text { Melihat } \\
\text { perubahan } \\
\text { visualization } \\
\text { suhu pada } \\
\text { blynk } \\
\text { dasboard }\end{array}$ & $\begin{array}{c}\text { Gauge meter } \\
\text { pada blynk } \\
\text { dasboard } \\
\text { berubah }\end{array}$ & Berhasil \\
\hline 5 & $\begin{array}{c}\text { Sensor } \\
\text { LoadCell }\end{array}$ & $\begin{array}{c}\text { Mengurangi } \\
\text { wadah pakan } \\
\text { mencapai } 400 \\
\text { gram }\end{array}$ & $\begin{array}{c}\text { Notifikasi } \\
\text { "Pakan telah } \\
\text { habis" tampil } \\
\text { pada aplikasi } \\
\text { blynk }\end{array}$ & Berhasil \\
\hline 6 & RTC & $\begin{array}{c}\text { Mematikan } \\
\text { dan } \\
\text { menyalakan } \\
\text { ulang RTC } \\
\text { setelah RTC di } \\
\text { set }\end{array}$ & $\begin{array}{c}\text { Waktu RTC } \\
\text { sama dengan } \\
\text { waktu } \\
\text { sekarang }\end{array}$ & Berhasil \\
\hline 7 & Motor Servo & $\begin{array}{c}\text { Menggerakkan } \\
\text { Motor Servo }\end{array}$ & $\begin{array}{c}\text { Motor Servo } \\
\text { membuka }\end{array}$ & Berhasil \\
\hline
\end{tabular}




\section{Kesimpulan}

Berdasarkan data hasil penelitian dan pembahasan yang telah diuraikan di atas, maka dapat diambil kesimpulan :

1. Pembuatan alat monitoring suhu dan pemberi pakan otomatis ayam anakan berbasis loT sudah berfungsi dengan baik walaupun ada beberapa kekurangan.

2. Menampilkan hasil bacaan sensor pada aplikasi blynk, mengirimkan notifikasi "pakan telah habis" ketika wadah pakan sudah mencapai berat kosong yaitu $<=400$ gram sudah bisa berfungsi.

3. Lampu on untuk menghangatkan kandang ketika suhu mencapai pada titik terendah yaitu $<=26 \circ C$ dan akan off ketika suhu mencapai titik maksimal yaitu $>=29 \circ \mathrm{C}$ dan mengirimkan notifikasi pada aplikasi untuk peringatan "suhu terlalu tinggi".

4. Wadah pakan akan otomatis terbuka sesuai sistem penjadwalan pada RTC.

\section{Daftar Pustaka}

[1] R. S. Richi, "PERANCANGAN INTERNET OF THINGS SMART FARM UNTUK PENGATURAN SUHU PADA DAY OL CHICKEN (DOC)," 2018.

[2] R. K. Sebayang, O. Zebua, and N. Soedjarwanto, "Perancangan Sistem Pengaturan Suhu Kandang Ayam Berbasis Mikrokontroler," JITET J. Inform. Dan Tek. Elektro Terap., vol. 4, no. 1, pp. 1-9, 2016.

[3] A. B. Laksono, "Rancang Bangun Sistem Pemberi Pakan Ayam Serta Monitoring
Suhu dan Kelembaban Kandang Berbasis Atmega328," J. Elektro, 2017, doi: 10.30736/je.v2i2.86.

[4] D. Kurnia and V. Widiasih, "Pemberian Pakan Ayam Otomatis Dan Presisi," vol. 11, no. 2, 2019.

[5] N. Lestari, K. Abimanyu, I. H. Setyo, and D. Hadian, "Rancang bangun pengatur suhu kandang ayam untuk perternakan ayam skala kecil," vol. 13, no. 1, pp. 114, 2020.

[6] I. Gunawan and H. Ahmadi, "Sistem Monitoring Dan Pengkabutan Otomatis Berbasis Internet Of Things (loT) Pada Budidaya Jamur Tiram Menggunakan NodeMCU dan Blynk," Infotek J. Inform. dan Teknol., vol. 4, no. 1, pp. 79-86, 2021, doi: 10.29408/jit.v4i1.2997.

[7] M. G. I. I Gunawan, T Akbar, "1 , 2 , 3," Prototipe Penerapan Internet Things Pada Monit. Lev. Air Tandon Menggunakan Nodemcu Esp8266 Dan Blynk, vol. 3, no. 1, pp. 1-7, 2020.

[8] M. F. Syukroni, "Rancang Bangun Knowledge Management Sistem Berbasis Web Pada Madrasah Mualimin AlIslamiyah Uteran Geger Madiun," Tek. Inform. Univ. Muhammadiyah Ponorogo, pp. 7-35, 2017.

[9] M. Gunawan, Indra; Sudianto, Aris; Sadali, "Alat Pengukur Suhu Tubuh Berbasis Internet of Things ( loT ) Menggunakan ESP8266 dan Firebase Measuring Body Temperature Based Internet of Things ( IoT ) Using Esp8266 and Firebase," vol. 11, no. 1, pp. 91-100, 2021.

[10] D. Wijanarko and S. Hasanah, "Monitoring Suhu Dan Kelembaban Menggunakan Sms Gateway Pada Proses Fermentasi Tempe Secara Otomatis Berbasis Mikrokontroler," J. Inform. Polinema, vol. 4, no. 1, p. 49, 2017, doi: 10.33795/jip.v4i1.144.

[11] J. S. Saputra and Siswanto, "Prototype Sistem Monitoring Suhu Dan Kelembaban 
Pada Kandang Ayam Broiler Berbasis," vol. 7, no. 1, 2020.

[12] G. Mussardo, "RANCANG BANGUN SISTEM MASUK PARKIR MOTOR DENGAN RFID BERBASIS NODEMCU ESP8266," Stat. F. Theor, vol. 53, no. 9, pp. 1689-1699, 2019, doi: 10.1017/CBO9781107415324.004.

[13] E. Wiji, S. Budianto, and A. H. Kridalaksana, "Kelembaban Kandang Ayam Boiler Berbasis Mikrokontroler Atmega328," Pros. Semin. Nas. Ilmu Komput. dan Teknol. Inf., vol. 2, no. 2, 2017.

[14] R. F. Kafafi, "Rancang Bangun Monitoring Suhu Dan," Mhs. Tek. Inform., vol. 3, no. 2, pp. 98-104, 2019.

[15] F. D. Putra, A. Sularsa, and D. R. Suchendra, "Implementasi Pengontrol Pakan Ternak Menggunakan Sensor Ultrasonik Berbasis Arduino Uno," eProceeding Appl. Sci., vol. 4, no. 3, pp. 1958-1963, 2019.

[16] E. Mandayatma, "Peningkatan Resolusi Sensor Load Cell Pada Timbangan Elektronik," J. Eltek, vol. 16, no. 1, p. 37, 2018, doi: 10.33795/eltek.v16i1.85.

[17] Handi, H. Fitriyah, and G. E. Setyawan, "Sistem Pemantauan Menggunakan Blynk dan Pengendalian Penyiraman Tanaman Jamur Dengan Metode Logika Fuzzy," J. Pengemb. Teknol. Inf. dan IImu Komput., vol. 3, no. 4, pp. 3258-3265, 2019.

[18] M. A. Zainudin, "Model Sistem Pemberi Pakan Pada Ternak Ayam Petelur Berbasis SMS Gateway," Progresif J. IIm. Komput., vol. 15, pp. 89-96, 2019. 